\title{
Internet Re
}

VALUE CO-CREATION IN FIRM SPONSORED ONLINE COMMUNITIES: WHAT ENABLES, CONSTRAINS, AND SHAPES

VALUE

\begin{tabular}{|r|l|}
\hline Journal: & Internet Research \\
\hline Manuscript ID & INTR-05-2019-0205.R3 \\
\hline Manuscript Type: & Research Paper \\
\hline Keywords: & $\begin{array}{l}\text { Online co-creation community, value co-creation, literature review, } \\
\text { online community }\end{array}$ \\
\hline \multicolumn{2}{|l}{} \\
\hline
\end{tabular}

\section{SCHOLARONE ${ }^{m}$ \\ Manuscripts}


Citation

Priharsari, D., Abedin, B. and Mastio, E. (2020), "Value co-creation in firm sponsored online communities: What enables, constrains, and shapes value", Internet Research, Vol. ahead-of-print No. ahead-of-print. https://doi.org/10.1108/INTR-05-2019-0205

\title{
VALUE CO-CREATION IN FIRM SPONSORED ONLINE COMMUNITIES: WHAT ENABLES, CONSTRAINS, AND SHAPES VALUE
}

\author{
Diah Priharsari, Babak Abedin, Emmanuel Mastio
}

\begin{abstract}
Purpose - The purpose of this paper is (i) to explore enablers and constraints in value co-creation in sponsored online communities, and (ii) to identify firm roles in shaping value co-creation. The structured analysis is translated into strategies for practitioners and for guiding future research.
\end{abstract}

Design/methodology/approach - We systematically review and synthesise the literature to develop a comprehensive model of value co-creation.

Findings - Our literature review findings have: (i) led to the identification of four actors in sponsored online communities, (ii) revealed enablers and constraints for value co-creation in online communities, and (iii) provided insight into the simultaneous roles of sponsoring firm (co-creator and facilitator) and the interrelationship between them.

Research limitations - Like other systematic literature review studies, the findings are limited by what was reported in the papers selected for the review. We contribute to service dominant logic by bridging the macro level to the empirical level, and add to our understanding of the sociomateriality theory by capturing constraints and enablers coming from various actors.

Practical Implications - The extracted enablers and constraints guide decision makers to better design, asses, monitor, and support sponsored online communities. The findings also inform how to orchestrate the two sponsoring firm roles so that the online community is still attractive for the members and creates value for the sponsoring firm.

Originality/value - Given the variety of disciplines dealing with value co-creation, and given the plenitude of definitions and related concepts, this study consolidates the existing knowledge and models how value is co-created in online communities.

Keywords - Online co-creation community; value co-creation; literature review; online community

\section{Introduction}

In recent years, co-creation online communities have gained a reputation in involving enthusiastic consumers in a company's development processes through networked interactions between the firm and the consumers. These interactions unfold as a co-creation process, a cooperative phenomenon that reflects a shift in thinking from the firm as a definer of value to more participative customers (Frasquet-Deltoro et al., 2019; Ind and Coates, 2013). A well-managed co-creation process has clear benefits for the organisation; it can lead to successful innovations, new business opportunities, cost reduction, and an expanded customer base (Fisher, 2019; Ind et al., 2013; Park et al., 2019). Thus, various firms have begun to incorporate individuals from outside their organisation in their value creation process through firm sponsored online communities. Successful examples of firm sponsored online communities can be found in various sectors such as Aston Martin Community in the automotive sector (Essamri et al., 2019), SAP in computers (Tavakoli et al., 2017), Huafen club for 
Huawei mobile phones (Zhao et al., 2019), and Starbucks in the café and restaurant industry (Wong et al., 2016). This has motivated growing research interest in understanding value co-creation in firm sponsored online communities (Frasquet-Deltoro et al., 2019).

Firm sponsored online communities have been described as initiatives sponsored by a firm to cocreate value with their external product or service users (Yan et al., 2018). Firm sponsored online communities are different from traditional organisations because of their fluidity and the extent to which they depend on voluntary participation (Faraj et al., 2011; Lusch and Nambisan, 2015). In online communities, the sponsoring firm lacks authority to issue commands and the individual participants are not obligated to obey. A firm sponsored online community is an organisation where most individual participants come and go easily, while the sponsoring firm does not change. Therefore, the firm is assumed to have the responsibility of coordinating value co-creation, which is called orchestration (Nambisan et al., 2017).

While there is a lot of support in extant literature for taking advantage of customer engagements in these communities (e.g. Pee, 2016; Tavakoli et al., 2017; Zhang and Luo, 2016), there is currently a lack of comprehensive analyses of these communities as a fluid organisation. The existing studies are scattered all over and difficult to be summarised into a broad view mainly because of the contextual nature and the fast pace of emergence of applications and their implications for online communities (Bailey et al., 2019; Felin et al., 2017). In addition, how various actors may contribute to value creation remains unclear and is still emerging with limited integration efforts (Bugshan, 2015; Faraj et al., 2016; Ind et al., 2013; Singaraju et al., 2016). Previous studies in the literature primarily emphasise one particular actor. For example, some studies consider the technology solely as the context rather than an actor with its own capabilities (Singaraju et al., 2016). Other research focuses either on the firm's or individual's perspective and neglects other determinism (Monteiro, 2018; Suseno et al., 2018). Therefore, it is not surprising that there are recent calls from scholars (Faraj et al., 2015; Nambisan et al., 2017) for more research into understanding online communities by considering all actors involved and the leading collaboration in online communities.

Given the above, this study aims to address how firm sponsored online co-creation communities enable, constrain, and shape value creation as a collective action of members. To answer this question, we examine the firm's different roles in shaping value co-creation in online communities, as a collective action of members, and present the corresponding enablers and constraints. The study makes two primary contributions: (i) it uncovers enablers and constraints of value co-creation in firm sponsored communities and proposes a new framework for classifying them based on actors in the communities, and (ii) it identifies firm roles involved in value co-creation in these communities and presents their association with enablers. Findings will extend our current understanding of how the 'interaction between actors' is fundamental to value co-creation in online communities. The fluidity of the organisational structure is primarily influenced by how individual participants make meanings of the online community. Therefore, this study takes the individual participant's perspective to answer the research question. We do this by systematically reviewing and synthesising the literature to develop a comprehensive understanding of value co-creation in firm sponsored online communities, conceptualise what shapes value co-creation in these communities, and develop an agenda for future research. In our study, value co-creation is considered to occur through the collective action of community members, including both the firm and individual participants, with the assistance of technology. Thus, we draw upon service dominant logic (SDL) to conceptualise the relationship between the firm and individuals. We also use sociomateriality to theorise the interaction between the firm and individuals with the technology and refer to the affordance lens to investigate the technology. 
The remainder of the paper is organised as follows: Section 2 presents the background and gaps in the literature; Section 3 discusses our methodology for the systematic literature review; Sections 4 and 5 present the findings and discussion, respectively; Sections 6 and 7 highlight implications for theories and practice, as well as recommendations for future studies; and lastly, the paper concludes with a summary of our contribution, including its limitations, in Section 8.

\section{Actors in Online Co-Creation Ecosystem}

\subsection{Theoretical Background}

Value is often seen as the relationship between what one benefits and what one sacrifices (Grönroos, 2011a). Various scholars have taken different approaches to explore enablers and constraints of value co-creation, and present what actors are involved in firm sponsored online communities and how they may be related. Some studies emphasise the firm's capability to transform ideas into implementation, including the involvement of employees, to produce value for the firm (Dong and Wu, 2015; Yan et al., 2018). Other studies emphasise the interactions between members in online communities as a key element of value co-creation in online communities (Grönroos and Voima, 2013; Suseno et al., 2018). Here, scholars shift the idea of value co-creation from a firm dominated perspective to another stakeholders' perspective. Henfridsson et al. (2018) introduce a way to further involve technology in value co-creation and emphasise the influence of participants in selecting how to use the technology, which may deviate from its original purposes. These studies show that understanding value cocreation in a fluid organisation is challenging because of reifying the agency of actors caused by reducing the complexity of interactions in the digital environment (Holmström, 2018).

While previous literature stresses the importance of interactions between the sponsoring firm and individual participants, they often focus on either the firm or the participants but not the interaction between them. For example, Zwass (2010) provides a taxonomy of co-creation based on characteristics attached to the sponsoring firm and individual participants, yet ignores the collective interaction that occurs during co-creation which serves as the foundation of value co-creation (Briel and Recker, 2017; Heidenreich et al., 2015). Furthermore, many studies consider technology as the context rather than an actor with its own capabilities (Singaraju et al., 2016); hence there is a gap in the academic literature regarding resources that might be present in the technology and their essential impact on value co-creation (Storbacka et al., 2016; Zhang et al., 2017; Zwass, 2010). A focus on the interactions in firm sponsored online communities is important as it can pave the way for the development of theories that are relevant to practice (Felin et al., 2017). Another gap in the current literature is a lack of comprehensive understanding of what enables or constrains value co-creation in sponsored online communities. Faraj et al. (2011) propose fluidity as an enabler of value creation in online communities. The individual's aspect is also recognised for its contribution to enabling value co-creation (Zhang et al., 2015a). Nambisan (2009) presents critical dimensions of personal value experiences in co-creation, with a limited focus on examining enablers and constraints. Despite these studies, more research is needed to generate an integrated model that presents what enables or constrains value co-creation in online communities. This is particularly important since previous studies have overlooked theoretical perspectives for reporting enablers and constraints, which makes it difficult to compare findings across different studies.

\subsection{Developing a Theoretical Foundation}

Value co-creation in firm sponsored communities is commonly used to describe the participative process between people and a sponsoring firm to generate value (Grönroos, 2008; Payne et al., 2008; Prahalad and Ramaswamy, 2002; Vargo and Lusch, 2004). Vargo and Lusch (2004) introduce a perspective to value co-creation, which moves the focus on value from tangible outputs to a service 
dominant logic (SDL). Through the perspective of SDL, value is a dynamic, experiential, and contextual benefit provided by a service contributed by actors in the service ecosystem (Barrett et al., 2015; Kelleher et al., 2019; Vargo and Lusch, 2016). The recent development of SDL has moved away from designating specific roles to different parties engaging in value co-creation and has emphasised that no differences exist between producers and consumers in a service ecosystem. This does not mean that all actors are identical (Vargo and Lusch, 2016). The notion of the generic actor presupposes that all actors engaged in the process of benefiting from their own existence also benefit from the existence of others. Furthermore, generic actors are used to investigate a wider perspective of service as a service ecosystem. However, value should be created in instances (Fisher, 2019; Grönroos and Voima, 2013). Therefore, in this study, we differentiate the sponsoring firm and the individual participants because we want to expose the organisation's fluidity, which is different from the interaction in business-to-business relationships in terms of the lack of existence of formal contracts and the freedom to leave or to participate (Faraj et al., 2016).

Given the above, we conceptualise the engagements in sponsored online communities between the sponsoring firm and individual participants as an ecosystem. This ecosystem comprises two subsystems inspired by Grönroos (2011b, 2019). In the first sub-system, it is the firm's responsibility to invite participants for co-production and resource integration. As a result, this sub-system is directly engaged in value co-creation. Whereas in the second sub-system it is the participants who actively engage with their peers in value co-creation. In this sub-system, the firm plays the facilitator role. These two subsystems (value co-creation and value facilitation) spontaneously sense and respond to each other to maintain organisational fluidity (Vargo and Lusch, 2016; Winkler and Wulf, 2019).

SDL provides a macro orientation of co-creation, and thus we can use the sociomateriality lens to zoom out on each actor of value co-creation. Through sociomateriality, routines are the result of imbrications of human and material agencies (Leonardi, 2011). In SDL, routines are equivalent to resource integration as explained by Singaraju et al. (2016). Thus, 'human' and 'technology' can also be seen as actors in SDL that develop service ecosystems together (Kannan et al., 2019). Whether technology is used in a person's routines depends on the human interpretation of the technology's features and how far they are able to adapt to each other. Thus, building on sociomateriality and SDL, we theorise enablers and constraints of value co-creation into four categories: firm, technology, individual participants, and social. Sociomateriality's critical realism differentiates 'social' from 'individuals' (Faulkner and Runde, 2013), whereby 'social' reflects interaction between actors. While we recognise that there are different approaches in theorising sociomateriality, agential realism and critical realism (Leonardi, 2013), this study uses a critical realism approach which incorporates the effect of agency in sociomateriality phenomena. The critical realism approach has been selected because recent studies have revealed the influence of social aspects in online value co-creation (e.g. Fisher, 2019; Frasquet-Deltoro et al., 2019; Osatuyi and Turel, 2019) which indicate the importance of highlighting social as a different actor from individual participants.

To disentangle the intertwining of sociality and technology in online communities, Mynatt et al. (1998) recommend exploring dimensions that represent a balance between technological and human elements, that is, affordances. Affordance is described as "possibilities for action ... between a technology and the users that enable or constrain potential behavioural outcomes in a particular context" (Evans et al., 2017, p. 36). Using a relational approach to affordances is useful to explain the consistency of effects within and across organisations; when focusing on relationships and not on the property of technology (Dinsmore, 2019; Treem and Leonardi, 2012). Thus, we refer to Evans et al. (2017) and Treem and Leonardi (2012) to classify enablers and constraints for technology. 
Figure 1. Methodological Phases

\subsection{Initiation and Selection}

\subsubsection{Criteria Definition}

Criteria definition can be formulated through a combination of knowledge, brainstorming (Gamble et al., 2016), and expert opinion (Kitchenham, 2007). In addition, alternative terminology and inherent application categories or practices can be used as additional key terms (Gamble et al., 2016). For this systematic literature review, the key terms were chosen based on the research questions. These keywords were value, creation, and online environment or online community. This ensured we did not filter results based on the type of online communities. Accordingly, these three terms and additional alternative terminologies were used as the initial strings. "Virtual" was also used because some papers from the first cycle of searching used "virtual" to express "online". Searches were conducted across titles, abstracts, and keywords.

\section{("Value" or "benefit") AND "creation" AND ("online" or "virtual")}

Tranfield et al. (2003) advise researchers to limit the subject area or topics for a search because when the results cover autonomous sub-fields, researchers may struggle with an overload of information and the creation of transdisciplinary understanding. Accordingly, one set of results can be considered more relevant compared with others if the subject areas are closer to the main study. Thus, we selected computer science, business, management, and accounting as the subject areas. We also included social sciences to cover social aspects of online communities. The search was limited to papers written in English. In addition, instead of using separate databases such as EBSCO, ScienceDirect, and the Association for Computing Machinery Digital Library, we used Scopus as our source for the search that includes papers from all major databases.

\subsubsection{Search and Selection of Primary Studies}

The selection of primary studies comprised six steps. Figure 2 illustrates how the 1,947 total identified references from the keyword selection were filtered. We started with keywords, followed by the application of inclusion criteria. We found 665 papers that met the inclusion criteria. The next step 
was to screen the title, followed by an assessment of the abstract and finally a screen of the body text. The four actors, as identified earlier, were used as the screening criteria for the title, abstract, and the body: individual participants, using an online environment (it could be only an online environment or a mix between online and offline environments), users' perspectives, business-to-customer and customer-to-customer in an environment sponsored by a firm, and peer-reviewed journals. Each screening was conducted twice and Cohen's kappa was calculated to examine the reliability of the selection (Kitchenham, 2007). Manifestations of reliability were: stability (the process is unchanging over time), reproducibility (replicability), and accuracy (the process conforms to its specification) (Krippendorff, 1989). Finally, we selected the 35 documents that met all the criteria for the review.

Screening the title, abstract, and body of the text produced a Cohen's kappa value above 0.4 ( 0.6 for title screening, 0.7 for abstract screening, and 0.6 for body text screening), which according to De Wever et al. (2006) is at an acceptable level and reflects the stability and accuracy of the selection. Disagreements in the selection were resolved by combining the first and second screening results. In the last selection stage, disagreements were resolved by reading the body of the text for a third time and a decision was made accordingly.

Wolfswinkel et al. (2013) suggest that forward and backward citation should be undertaken until no new relevant papers are found. A simple scan of the references is suggested by MacDonell et al. (2010). We used the latter approach, as the number of initial primary studies was adequate (35 papers) and realistic due to time constraints. First, we conducted the backward search by scanning reference lists and then used Google Scholar to identify additional related papers (forward search). After we added the result of both the backward and forward searches, 54 studies were identified. 
(“Value" or "benefit") AND “creation" AND ("virtual consumer environment" or "online" or "virtual")

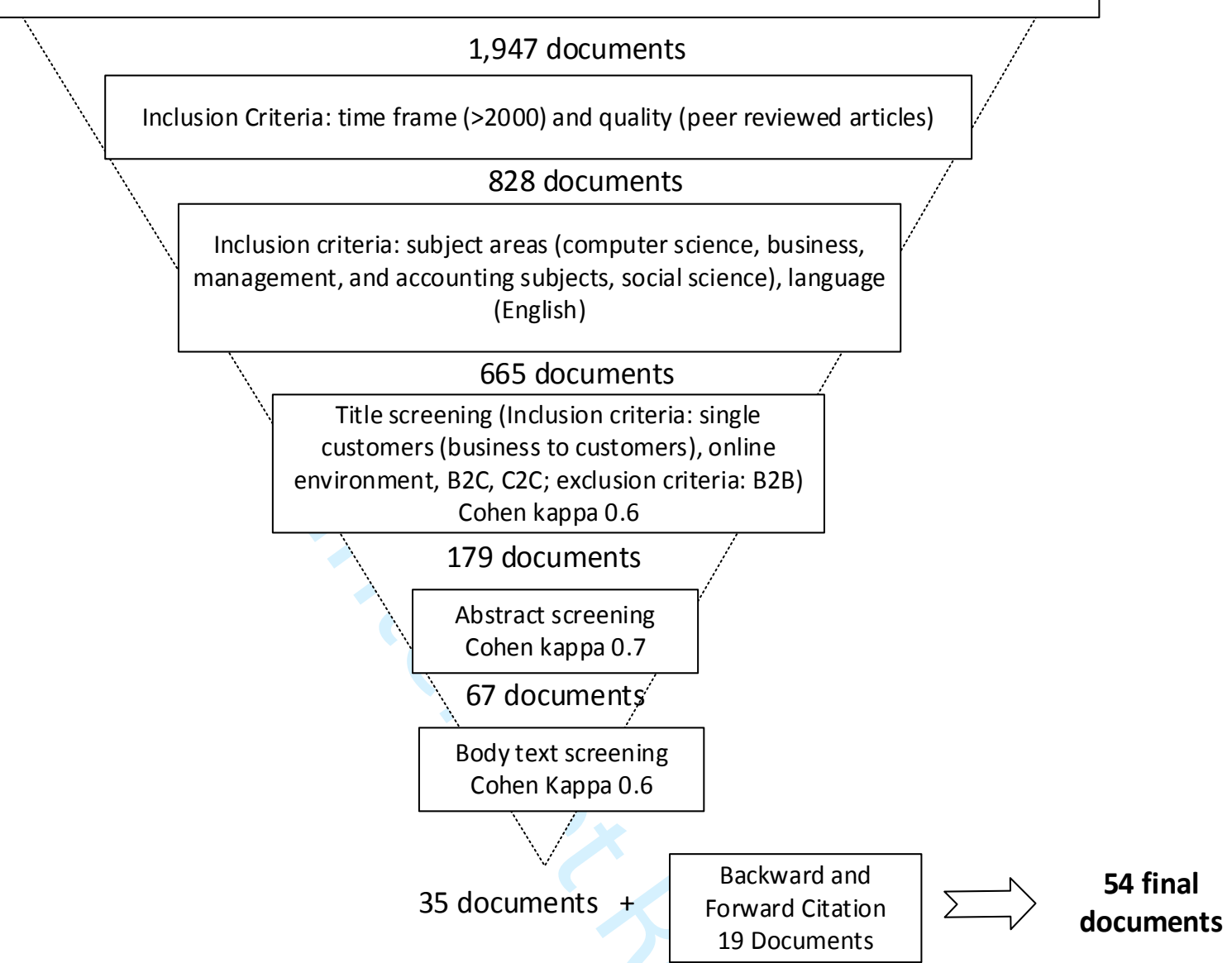

Figure 2. Systematic Review Process

\subsection{Coding Procedure}

We conducted a primarily inductive analysis of each of the selected publications, and examined the body of their text. We identified and classified concepts relevant to value co-creation. To extract enablers and constraints, we included papers with empirical evidence as well as review papers. We then extracted enablers and constraints as well as their corresponding description, and classified them into 'technology', 'firm', 'individual', and 'social'. The first author came up with the first iteration of this classification, and the second and third author completed the second iteration. Disagreements were resolved by going back to the original papers and examining the context and descriptions associated to each item. As an example of how we conducted the coding procedure, Chen et al. (2012) reported "firm sponsoring feedbacks" and "sponsoring firm responses" as important concepts in relation to individual participation in co-creation initiatives. In addition, (Nambisan and Nambisan, 2008) found that the sponsoring firms respond to customers' input, and develop plans for formal and informal communication. Thus, we encapsulated these findings into a category called formal and Informal communication. Next, we grouped categories into themes. For example, formal and informal communication, share decision making, activity development, and identify creative customers were classified under a theme called Participatory Leadership. We repeated this process for all the selected papers. Table 1 provides samples of quotes and findings for each theme and Table 2 presents the categories included under each theme. 


\subsection{Quality Assessment of the Review}

We used the following strategies to assess the quality of the review. Firstly, as recommended by Boell and Cecez-Kecmanovic (2015) and with regard to the research questions, we explained the reason for the systematic literature review as well as its protocols under Introduction and Background. Secondly, to improve the reliability of the selected studies for this review, we used Cohen's kappa as suggested by Kitchenham (2007). Lastly, we used process validation and report validation to increase the validity of our systematic literature review. Process validation was conducted by the second and third author to assess the inclusion and exclusion criteria, the protocol, and the provision of single steps that can potentially be replicated by other researchers (Brereton et al., 2007). Report validation was done by conducting internal and external reviews (Brereton et al., 2007; Kitchenham, 2007), with the second and third author conducting the review to validate the results that were initially found by the first author. Additionally, five external experts reviewed the protocol and findings, and provided detailed feedback. Revisions were made based on their reviews.

\section{Findings}

\subsection{Primary Study Map}

A primary study map was developed to provide the context for the analysis (Brereton et al., 2007) and to systematise the important elements of the selected studies (Boell and Cecez-Kecmanovic, 2014). The following items were extracted from the selected studies and were included in the study map: (i) demographic details of the studies (source, authors, year, disciplines, type of study); (ii) research design (collection and analysis, literature review, empirical study), (iii) research abstract and questions, and (iv) findings of reviewed studies and relevant body of the text.

Selected papers in this review were published from 2000 to mid-2017. Research into online collaborative communities have been dominated by quantitative research: $44 \%$ of studies were quantitative versus $32 \%$ qualitative and $11 \%$ used mixed methods (Figure 3 ). The most commonly used methods were surveys, interviews, and content analysis. Most studies examined existing co-creation communities as the context of the study, and conducted qualitative or quantitative methods to study the community and its members. Only one study used action research (Kohler et al., 2011) and another study conducted literature review (Zhao and Zhu, 2014). The scope of the latter study was limited to the concepts and applications of crowdsourcing, and called for scholars to further study the crowdsourcing context from participant, firm, and system perspectives.

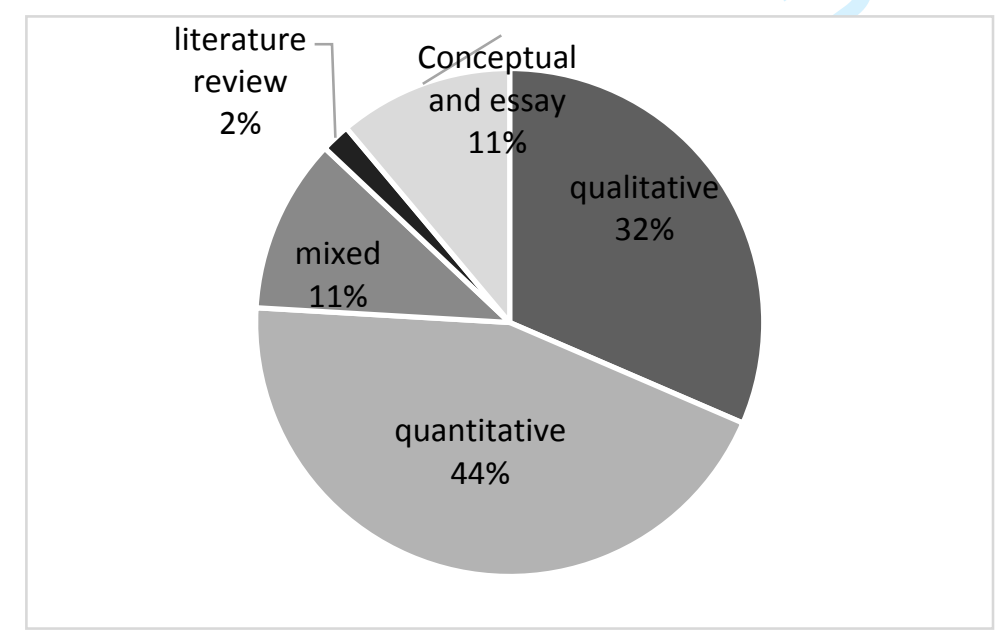

Figure 3. Data Analysis and Disciplines 
Given the importance of theories in the information systems (IS) research (Mueller and Urbach, 2017), we also looked at the distribution of theories used in the selected papers (Figure 4). We found that 36 of the 54 studies (67\%) drew on 25 theories to provide a theoretical basis to explain, describe, or predict their corresponding research questions (Figure 4). Our findings projected a higher level of adoption of theories than Zhao and Zhu (2014) review of crowdsourcing in which only nine of 55 papers provided a theoretical basis. We found that service-dominant logic (12 studies) followed by social capital theory ( 5 studies) were the most cited theories in our selected studies.

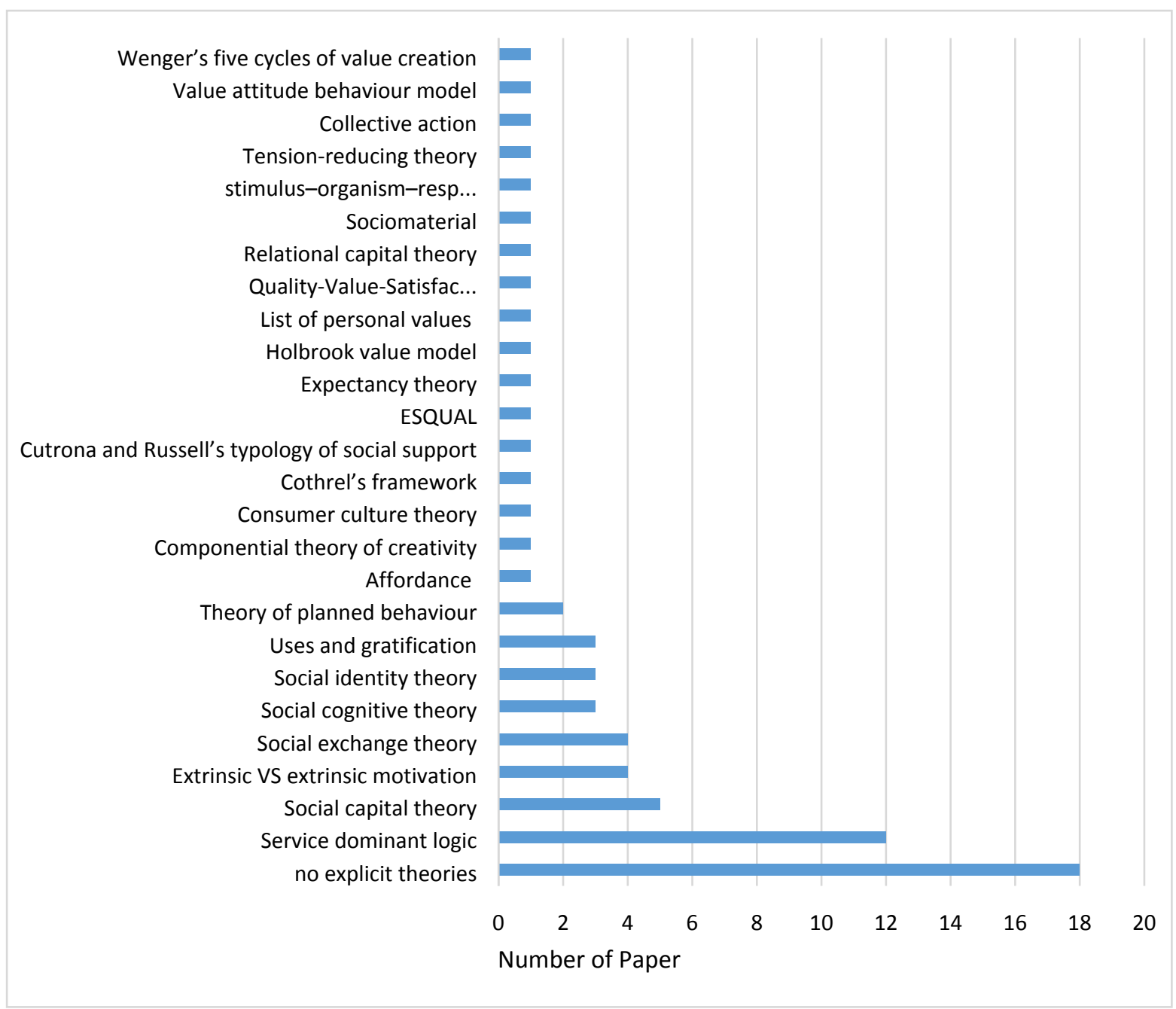

Figure 4. Theories Used in the Literature

\subsection{What are the Enablers and Constraints in Sponsored Online Communities?}

We classified enablers and constraints into four categories reflecting four actors (Table 2): Firm, Technology, Individual Participants, and Social. Firm reflects the firm that sponsors the online community, Technology is the online platform that hosts the community, Individual Participants are members of the community, and Social is the interaction between Technology, Firm, and Individual Participants.

We firstly extracted enablers and constraints from the different studies, and then aggregated them based on their similarities. The underlying subcategories for Social, Individual Participants, and Firm represent the enablers that emerged from our analysis of the selected papers. However, for Technology, subcategories were informed by threshold criteria for substantiating purported affordances (Evans et al., 2017), in which the name of each enabler was inspired by corresponding 
definitions in Treem and Leonardi (2012). For example a feature called "library tool" is used by teachers to share their material (Booth and Kellogg, 2015), which helped teachers to locate teaching material shared by others. Treem and Leonardi (2012) called this interpretation of technology as Visibility affordances. Therefore, we categorised that as Visibility under technology.

Examples of excerpts for each enabler are presented in Table 1.

Table 1. Sample quotes

\begin{tabular}{|c|c|}
\hline Enabler & Sample quote \\
\hline Participatory Leadership & $\begin{array}{l}\text { "...actively engaging community members in management and decision } \\
\text { making in order to avoid or solve conflicts and create understanding." } \\
\text { (Gebauer et al., 2013, p. 1522) }\end{array}$ \\
\hline Reward System & $\begin{array}{l}\text { "For example, every year Microsoft selects Most Valuable Professionals } \\
\text { from customers who contribute to the product support" (Nambisan and } \\
\text { Nambisan, 2008, p. 58) }\end{array}$ \\
\hline Transparency & $\begin{array}{l}\text { "...managing customer expectations and minimizing potential negative } \\
\text { outcomes. This requires a high degree of transparency." (Nambisan and } \\
\text { Nambisan, 2008, p. } 60 \text { ) }\end{array}$ \\
\hline Content Quality & $\begin{array}{l}\text { "content quality aspects are the critical elements to deliver value } \\
\text { through an online community" (Seraj, 2012, p. 215) }\end{array}$ \\
\hline Equality & $\begin{array}{l}\text { "people should help those who have helped them by returning } \\
\text { equivalent benefits" (Wiertz and de Ruyter, 2007, p. 352) }\end{array}$ \\
\hline Sense of Community & $\begin{array}{l}\text { "Sense of community has a positive influence on customers' attitudes } \\
\text { towards engagement" (Zhang et al., 2015b, p. 319) }\end{array}$ \\
\hline Similarity & $\begin{array}{l}\text { "The members believe that common experiences and a shared vision } \\
\text { help them understand one another more easily and better, facilitate } \\
\text { interactions among peers" (Zhao et al., 2015, p. 77) }\end{array}$ \\
\hline Trust & $\begin{array}{l}\text { "Mutual caring and a feeling of being safe were common in } \mathrm{OHC} \\
\text { members' interactions. These factors also significantly influenced } \mathrm{OHC} \\
\text { members' interactions, including whether they were willing to talk } \\
\text { openly about personal difficulties or express needs for help." (Zhao et } \\
\text { al., 2015, p. 77) }\end{array}$ \\
\hline Association & $\begin{array}{l}\text { "C2C interactions-related cues in engagement platforms promote } \\
\text { interpersonal communication, favoring the development of high-quality } \\
\text { relationships with other customers" (Blasco-Arcas et al., 2014, p. 398) }\end{array}$ \\
\hline Interactivity & $\begin{array}{l}\text { "Influenced by interactivity and media richness (e.g., Steuer 1992), } \\
\text { virtual worlds can increase telepresence (Suh and Lee 2005). } \\
\text { Telepresence can be understood as the sensation of 'being there' in a } \\
\text { mediated environment in time and place" (Kohler et al., 2011, p. 774) }\end{array}$ \\
\hline Persistence & $\begin{array}{l}\text { "In particular, several NSTA LC members noted the ways in which the } \\
\text { Portfolio Tool and the 'LibraryTool' enabled them to more effectively } \\
\text { leverage growing knowledge capital." (Booth and Kellogg, 2015, p. 690) }\end{array}$ \\
\hline Visibility & $\begin{array}{l}\text { "refer to all descriptors on the site that facilitate and enable the } \\
\text { customer's goal attainment" (Zhang et al., 2015a, p. 469) }\end{array}$ \\
\hline Motivation & $\begin{array}{l}\text { "The results indicate that customer participation in co-creation projects } \\
\text { is motivated by four distinct types of benefits and also that co-creating } \\
\text { customers differ in their motivational level." (Constantinides et al., 2015, } \\
\text { p. 21) }\end{array}$ \\
\hline Personal Attribute & $\begin{array}{l}\text { "...a specific personality type leads to a diversity of usage ... influence the } \\
\text { motivational factors for users to contribute to innovation activities." } \\
\text { (Ståhlbröst and Bergvall-Kåreborn, 2011, p. 311) }\end{array}$ \\
\hline
\end{tabular}




\begin{tabular}{|c|c|}
\hline Enabler & Sample quote \\
\hline Personal Evaluation & $\begin{array}{l}\text { "...customer perceptions regarding the extent to which interactions in } \\
\text { the VCE offer these four benefits will shape their actual participation" } \\
\text { (Nambisan and Baron, } 2007, \text { p. } 44 \text { ) }\end{array}$ \\
\hline \multicolumn{2}{|l|}{ Constraint } \\
\hline $\begin{array}{l}\text { Low Participatory } \\
\text { Leadership }\end{array}$ & $\begin{array}{l}\text { "Managers need to avoid the temptation to control the community and } \\
\text { instead need to create a flexible environment in which participants feel } \\
\text { free to engage in other conversations and activities they are interested } \\
\text { in ..." (Ind et al., 2013, p. 22) }\end{array}$ \\
\hline $\begin{array}{l}\text { Unsuitable Reward } \\
\text { system }\end{array}$ & $\begin{array}{l}\text { "...I do not think participants exchanged a lot of new, crucial knowledge. } \\
\text { Very few people put forward the sort of knowledge that might jeopardize } \\
\text { their chances of winning..." (Hall and Graham, 2004, p. 242) }\end{array}$ \\
\hline Low Personal Attribute & $\begin{array}{l}\text { "Interaction becomes stronger as human capital increases, and a reverse } \\
\text { relation also hold true" (Wu and Fang, 2010, p. 576) }\end{array}$ \\
\hline Low Visibility & $\begin{array}{l}\text { "Our findings suggest a more subtle process is present and that replacing } \\
\text { intermediaries by the use of self-service technology empowers only } \\
\text { certain consumers and not others. Hence, for some individuals co- } \\
\text { production does not lead to co-creation of value." (Harrison and Waite, } \\
2015, \text { p. } 516)\end{array}$ \\
\hline
\end{tabular}

Only a few constraints were reported in the selected papers compared to the enablers in the same categories. The constraints related to the firm are the temptation to control interactions in online cocreation communities (Ind et al., 2013) and the use of unsuitable reward systems (Hall and Graham, 2004). The temptation to control comes from low share decision making and activity development, which fall under Low Participatory Leadership. While technology assists in enabling co-creation, presenting too much information and complex features can inhibit value co-creation because that leads to a low Visibility to search and locate information, and a limited understanding of commands and features (Harrison and Waite, 2015). An individual related constraint that can inhibit value cocreation is the capacity for individuals to perceive and use the technology to interact with other actors (Harrison and Waite, 2015; Wu and Fang, 2010).

Unlike constraints, the selected studies reported a relatively long list of enablers of value co-creation in online communities. These enablers are often interrelated and can reinforce each other. For example, sense of community is built by the ability to develop a collective morality (Evans et al., 2017; Hall and Graham, 2004) that is embedded both in the technological system (e.g. Zhao et al., 2015) and the social system (Bugshan, 2015) to facilitate communication. A sense of community encourages interactivity affordances when there is an opportunity for all members to contribute on an equal basis (Stewart Loane et al., 2015). Interactivity in this context makes the connection between participants more attractive, playful (Seraj, 2012) and develops equality (Ind et al., 2013). Interactivity also creates the opportunity to develop trust and connection that can lead to a sense of community (Ind et al., 2013). In addition to that, Visibility affordances lead to transparency, which then encourage members to participate (Nambisan and Nambisan, 2008).

Table 2. Categories, Themes of Enablers, and Sources

\begin{tabular}{|l|l|l|}
\hline Enabler Theme & Description & Sources \\
\hline Firm & Listens and responds to the & (Chen et al., 2012; Gebauer et al., 2013; \\
\hline Participatory & community by proactively & Hasan and Rahman, 2017; Kohler et al., \\
& leveraging the power of the virtual & 2011; Nambisan and Nambisan, 2008) \\
\hline
\end{tabular}




\begin{tabular}{|c|c|c|}
\hline Enabler Theme & Description & Sources \\
\hline & $\begin{array}{l}\text { community to mutually benefit } \\
\text { consumers, for example, by } \\
\text { involving participants in decision- } \\
\text { making, this gives them the } \\
\text { freedom to share their opinion. }\end{array}$ & \\
\hline Reward System & $\begin{array}{l}\text { Refers to the incentives, financial } \\
\text { or non-financial, that the provider } \\
\text { gives to encourage customer's } \\
\text { participation in value co-creation. }\end{array}$ & $\begin{array}{l}\text { (Füller, 2006; Hall and Graham, 2004; } \\
\text { Hasan and Rahman, 2017; Jeppesen and } \\
\text { Frederiksen, 2006; Nambisan and } \\
\text { Nambisan, 2008; Zhang et al., 2015b) }\end{array}$ \\
\hline Transparency & $\begin{array}{l}\text { Clarity and transparency related to } \\
\text { the process, role, and outcomes. }\end{array}$ & $\begin{array}{l}\text { (Hasan and Rahman, 2017; Nambisan and } \\
\text { Nambisan, 2008) }\end{array}$ \\
\hline \multicolumn{3}{|r|}{ 型 } \\
\hline Content Quality & $\begin{array}{l}\text { Usefulness and balance between } \\
\text { personal opinion and credible } \\
\text { information. }\end{array}$ & (Laing et al., 2011; Seraj, 2012) \\
\hline Equality & $\begin{array}{l}\text { The norm of reciprocity and } \\
\text { perception of fairness. }\end{array}$ & $\begin{array}{l}\text { (Gebauer et al., 2013; Wiertz and de } \\
\text { Ruyter, 2007) }\end{array}$ \\
\hline $\begin{array}{l}\text { Sense of } \\
\text { Community }\end{array}$ & $\begin{array}{l}\text { A feeling of belonging, which is } \\
\text { marked by shared consciousness, } \\
\text { shared rituals and traditions, and a } \\
\text { sense of moral responsibility. }\end{array}$ & $\begin{array}{l}\text { (Brodie et al., 2013; Bugshan, 2015; Chen et } \\
\text { al., 2012; Gebauer et al., 2013; Hall and } \\
\text { Graham, 2004; Healy and McDonagh, 2013; } \\
\text { Laroche et al., 2012; Nambisan and Baron, } \\
\text { 2007; Pongsakornrungsilp and Schroeder, } \\
\text { 2011; Wiertz and de Ruyter, 2007; Zhang et } \\
\text { al., 2015b; Zhao et al., 2015) }\end{array}$ \\
\hline Similarity & $\begin{array}{l}\text { Common connections, interests } \\
\text { and hobbies. }\end{array}$ & $\begin{array}{l}\text { (Brodie et al., 2013; Misra et al., 2008; Zhao } \\
\text { et al., 2015) }\end{array}$ \\
\hline Trust & $\begin{array}{l}\text { Safe feelings from the } \\
\text { environment, built from policies } \\
\text { and cultural norms, which enables } \\
\text { participants to express ideas and } \\
\text { to experiment with new ways of } \\
\text { approaching problems. }\end{array}$ & $\begin{array}{l}\text { (Laing et al., 2011; Seraj, 2012; Zhao et al., } \\
\text { 2015) }\end{array}$ \\
\hline \multicolumn{3}{|l|}{ Technology } \\
\hline Association & $\begin{array}{l}\text { The ability to establish } \\
\text { connections between individuals } \\
\text { and between individuals and } \\
\text { content. }\end{array}$ & $\begin{array}{l}\text { (Blasco-Arcas et al., 2014; Hasan and } \\
\text { Rahman, 2017) }\end{array}$ \\
\hline Interactivity & $\begin{array}{l}\text { The ability to enable members to } \\
\text { come together in different ways } \\
\text { such as collective or asynchronous } \\
\text { contribution by individuals. }\end{array}$ & $\begin{array}{l}\text { (Füller et al., 2009; Hasan and Rahman, } \\
\text { 2017; Kohler et al., 2011; Misra et al., 2008; } \\
\text { Nambisan and Nambisan, 2008; Seraj, } \\
\text { 2012) }\end{array}$ \\
\hline Persistence & $\begin{array}{l}\text { The ability to provide information } \\
\text { in the same form. }\end{array}$ & $\begin{array}{l}\text { (Booth and Kellogg, 2015; Hasan and } \\
\text { Rahman, 2017) }\end{array}$ \\
\hline Visibility & $\begin{array}{l}\text { The ability to locate information } \\
\text { related to knowledge, behaviour, } \\
\text { preferences, and communication } \\
\text { network. }\end{array}$ & $\begin{array}{l}\text { (Booth and Kellogg, 2015; Cheung and To, } \\
\text { 2016; Hasan and Rahman, 2017; Kohler et } \\
\text { al., 2011; Kang, 2014; Nambisan and } \\
\text { Nambisan, 2008; Zhang et al., 2015a) }\end{array}$ \\
\hline & & \\
\hline
\end{tabular}




\begin{tabular}{|c|c|c|}
\hline Enabler Theme & Description & Sources \\
\hline Motivation & $\begin{array}{l}\text { Reasons and benefits that the } \\
\text { individual receives. }\end{array}$ & $\begin{array}{l}\text { (Brodie et al., 2013; Bugshan, 2015; } \\
\text { Constantinides et al., 2015; Fernandes and } \\
\text { Remelhe, 2016; Füller, 2006, 2010; Kang, } \\
\text { 2014; Nambisan and Baron, 2007; Roberts } \\
\text { et al., 2014; Schaedel and Clement, 2010) }\end{array}$ \\
\hline $\begin{array}{l}\text { Personal } \\
\text { Attribute }\end{array}$ & $\begin{array}{l}\text { Quality or characteristic of an } \\
\text { individual participant such as } \\
\text { interest, knowledge, and skills. }\end{array}$ & $\begin{array}{l}\text { (Füller, 2010; Hasan and Rahman, 2017; } \\
\text { Jeppesen and Frederiksen, 2006; Mai and } \\
\text { Olsen, 2015; Ståhlbröst and Bergvall- } \\
\text { Kåreborn, 2011) }\end{array}$ \\
\hline $\begin{array}{l}\text { Personal } \\
\text { Evaluation }\end{array}$ & $\begin{array}{l}\text { Refers to participant evaluation of } \\
\text { interaction experience, which } \\
\text { includes previous experiences, } \\
\text { affective evaluation, and the } \\
\text { assessment of what is gained and } \\
\text { what is given up in the online } \\
\text { community. }\end{array}$ & $\begin{array}{l}\text { (Blasco-Arcas et al., 2014; Füller, 2010; } \\
\text { Kang, 2014; Nambisan and Baron, 2007) }\end{array}$ \\
\hline
\end{tabular}

Figure 5 provides a sense of how much emphasis is given to each enabler and constraint by showing the breakdown of the frequency citations for each enabler. The top cited categories for each actor are Sense of Community in 'social', Motivation in 'individual', Visibility in 'technology', and Reward System in 'firm'. Only a few papers cite other categories. This figure suggests that the reviewed literature has covered all categories with largely focused on certain aspect within each category. 


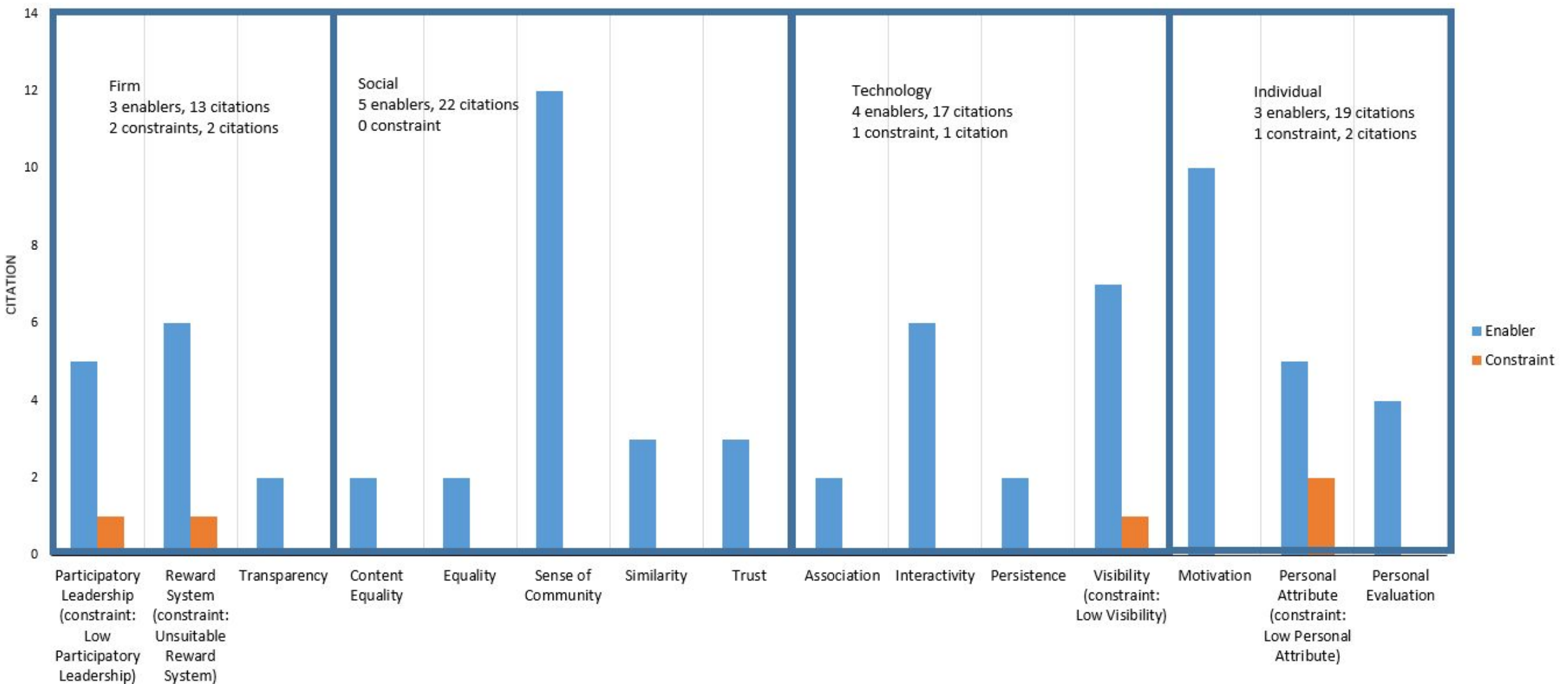

Figure 5. Breakdown of Citation to Enablers and Constraints 


\subsection{Firm Roles in Sponsored Online Communities to Co-Create Value}

The synthesis of results from the selected studies unpacks the fundamental role of firm roles in value co-creation and their associated enablers. Zhang et al. (2015b) explain the importance of making a distinction between the two firm roles, as a co-creator and as a facilitator, in nurturing collective action in online co-creation communities. Although other studies do not discuss much about the relationship between these roles, they implicitly demonstrate that facilitating and encouraging participants' engagement in co-creation activities will benefit both the firm and participants (e.g. Fernandes and Remelhe, 2016; Smaliukiene et al., 2015). Below we outline what each of the firm's roles entail and how they co-exist and are interrelated.

Firstly, when a firm takes a facilitator role, it needs to take the perspectives of other stakeholders equally into consideration. As a result, the focus in managing online communities switches from an economic-based approach to one that is more spontaneous and playful (Ind and Coates, 2013). This suggests that the sponsoring firm should let participants explore opinions and have fun with other participants without expecting any particular outcomes, but rather for the joy of doing so. As facilitator, however, the firm should be able to connect participants' common interests (Zhang et al., 2015b) because participants appreciate dialogue around topics of interest rather than questions and answers (Gummerus, 2010) and also the dialogue becomes an arena for them to socialise (Ind et al., 2013). These engagements develop social identity, a sense of community, trust and shared goals (Healy and McDonagh, 2013; Laroche et al., 2012; Zhao et al., 2015) that may bring benefits such as loyalty and sustainability for the online community (Brodie et al., 2013; Healy and McDonagh, 2013; Seraj, 2012; Zhang et al., 2017). However, this can lead to consequences such as an increased demand to control the firm. A study by Healy and McDonagh (2013) shows that strong engagement of individuals in the community may encourage them to seek more control over the co-creation process. Therefore, the sponsoring firm as a facilitator should be mindful of maintaining the balance between the firm's goals and the collective power coming from individuals in the online community.

Secondly, when the firm takes a co-creator role, it needs to engage actively with individual participants in the community (Füller et al., 2009; Zhang et al., 2017). In order to do this, the firm should understand what individual participants' needs and expectations are relating to their engagement with the sponsoring firm. As a co-creator, the firm should: pay attention to developing appropriate reward systems (Blasco-Arcas et al., 2014; Elsharnouby and Mahrous, 2015; Fernandes and Remelhe, 2016; Harrison and Waite, 2015); understand individuals internal and external participation motives (Braun et al., 2016; Fernandes and Remelhe, 2016); develop transparency in the processes and tasks and the selection of appropriate technologies to support tasks (Füller et al., 2009; Harrison and Waite, 2015; Nakatsu et al., 2014; Zhao et al., 2016).

Thirdly is the co-existence of these roles. Firm roles as co-creator and facilitator are complementary and interrelated (Blasco-Arcas et al., 2014; Bugshan, 2015; Ind et al., 2013; Misra et al., 2008; Nambisan and Baron, 2007; Nambisan and Nambisan, 2008; Wiertz and de Ruyter, 2007; Wu and Fang, 2010; Zhang et al., 2017). A study of value creation in a sponsored online community by Barrett et al. (2016) shows the importance of iterative and concurrent cycles of interactions between participants and the sponsoring firm to the business strategy. Interactions between participants are also positively associated with idea generation in co-creation (Chen et al., 2012; Wu and Fang, 2010). This shows that the co-existence of the two firm roles are necessary for long-term value co-creation in online communities. The co-existence of these roles is also important to minimise the negative reactions of participants' dissatisfaction. For example, the study by Gebauer et al. (2013) shows that social enablers help to reduce the damage caused by the dissatisfaction of co-creation by calming down the negative discussion. Although most studies imply the positive effect of the combination of these two 
roles, it is hard for individual participants to engage in collaboration in a competitive environment (Hall and Graham, 2004). This is because participants are afraid to lose their chance to win the competition. Aligned with this finding, Zhao et al. (2016) suggest that the orchestration of the facilitator and co-creation roles of the firm should be based on the types of tasks requested of the individual participants.

\section{Discussion}

Engaging with online communities has become increasingly important for companies, as these communities can contribute to the companies' digital and open innovation initiatives through strengthening the relationship between the firm and their consumer for product and service development (Nakatsu et al., 2014; Zhao and Zhu, 2014). The transition from innovation to the use of technology during the process of innovating presents a golden opportunity to be seized up upon by information systems researchers (Nambisan et al., 2017). The high visibility of peer communication in online communities has increased the chance for the sponsoring firm to co-create value with participants (Grönroos, 2019). Although previous studies have shown the benefits of sponsoring an online community for value co-creation, not many comprehensively report on what the beneficial critical factors from various actors are, nor do they report on how firms should coordinate voluntary participation. By using SDL, sociomateriality, and the affordance lens to generalise findings, this study has contributed to existing knowledge in two ways. Firstly, the findings reveal and disentangle enablers and constraints for the four defined actors: firm, technology, individual participant, and their inter-relationships ('social') as depicted in Figure 6. Secondly, the findings systematically uncover the importance of the firm roles in managing online communities, the associated enablers and constraints for each role, and the trade-off between each role.

\subsection{Enablers and Constraints for the Four Actors: Firm, Technology, Individual Participant, Social}

We found that constraints and enablers are the result of individuals' evaluation of the technology, the firm, the social, and themselves. Firm-related enablers stress the need for the sponsoring firm to listen and respond proactively to the online community. For example, Nambisan and Nambisan (2008) suggest modifying products or processes to respond to customer ideas and suggestions. Findings also highlight that the design of reward systems, clarity and transparency in processes, roles, and outcomes are also important for the firm in attracting and retaining individual participants to co-create value (e.g. Füller, 2006; Hall and Graham, 2004; Jeppesen and Frederiksen, 2006; Zhang et al., 2015b). Individual-related enablers represent three individual attributes: motivation, personal attributes, and evaluation toward the online community. While personal attributes influence consistent pattern of thoughts, feelings, and actions. Evaluation is a result of previous experiences and a comparison of what is given up with what is received in return. Positive evaluation will strengthen the participation in value co-creation. These attributes may either emerge internally from individual participants, or occur because of their interactions with peers in the online community (such as positive and negative feelings generated from their interactions). Technological enablers are individuals' interpretation of the technology, which manifest in association, interactivity, persistence, and visibility capabilities. For example, a repository tool in an online community for educators (Booth and Kellogg, 2015). The repository helps educators to share materials that they use in their classes. The repository keeps the material and shows it to other users in the same format. This persistence capability helps other educators to learn what others do in their classes. These capabilities enable members of the online community to interact and co-create value. 
The list helps the firm to evaluate their online community, understand their strengths, and develop appropriate strategies. For a firm that wishes to have long-term engagement with customers in an online community with no specific tasks, it becomes important to maintain the social enablers because they help in developing loyalty and sustainability for the online community (Brodie et al., 2013; Healy and McDonagh, 2013; Seraj, 2012; Zhang et al., 2017). On the other hand, if the firm has a clear agenda and they do not wish to engage with the participants in the long-term, the social enablers are not as important. As presented earlier (Section 4.2), social enablers affect and can be affected by technological enablers. Therefore, the decision of how much effort to dedicate to the development of social enablers influences the selection of types and technology attributes which support the online community.

Given that only four of the selected studies reported constraints (Hall and Graham, 2004; Harrison and Waite, 2015; Ind and Coates, 2013; Wu and Fang, 2010), there is little known about what limits value co-creation in firm sponsored communities. One hypothesis we found states that the ecosystem does not work well, which leads individuals to believe that some actors do not assist them in achieving their goals, which in turn may cause the individual to leave the community or not participate. The second hypothesis is that the ecosystem works well, but as it progresses, some members of the community may find the new environment non-compatible with their interests, skills, or other, personal factors. In this scenario, the community will stay active, but the individual may leave or stop participating. Once an individual leaves the community, the underlying reason for their departure will be lost, so therefore it is important for the firm to monitor the outflow and participation level continuously.

On the other hand, an enabler gives individuals an impression that other actors can help them to benefit from their engagement in the online community. Participants who join, stay alert to, and/or participate in online co-creation communities perceive the firm, the 'social', and the technology as affordances and enablers that help them produce value for themselves. This does not mean that constraints do not exist. The constraints may exist, but when individuals are challenged to create value, they may decide not to join the community or may leave the community in the absence of perceived value. Therefore, identifying constraints is challenging, particularly if we only consider 'active' participants as the source of data. These findings, in turn, call for and encourage future studies to empirically explore and extend our understanding of constraints in value co-creation in online communities.

\subsection{Firms Roles in Managing Online Communities}

Figure 6 integrates enablers, constraints, and the four actors in value co-creation ecosystems. The primary advantage of the classification framework is identifying, distilling, classifying, and integrating prior findings on value co-creation in firm sponsored online communities in a single framework. The firm's roles as a facilitator and co-creator develop sub-systems that spontaneously sense and respond to each other iteratively and concurrently in a service ecosystem. The ability to sense and respond actively will determine the continuation of value co-creation in online communities. Through listening and advocating participants' interactions, the sponsoring firm will be able to develop a detailed understanding of where the firm's offerings fit the customers' overall needs. On the other hand, participants also sense and respond to the firm's co-creation activities. The result of these activities will determine their relationships with others in the online community. Thus, value generation in one sub-system will influence engagement in another sub-system in an iterative manner. The use of technology makes the sensing more spontaneous. These ongoing cycles become the engine of value co-creation in online communities. 


\begin{tabular}{|c|c|c|}
\hline FIRM ENABLER AND CONSTRAINT & \multirow{7}{*}{ VALUE CO-CREATION ECOSYSTEM } & $\begin{array}{c}\text { INDIVIDUAL PARTICIPATION ENABLER } \\
\text { AND CONSTRAINT }\end{array}$ \\
\hline \multirow{2}{*}{$\begin{array}{l}\text { PARTICIPATORY LEADERSHIP } \\
\text { 1. Activity development } \\
\text { 2. Creative costumer identification } \\
\text { 3. Formal and informal communication } \\
\text { 4. Share decision Making }\end{array}$} & & $\begin{array}{l}\text { MOTIVATION } \\
\text { 1. Benefit } \\
\text { 2. Commitment } \\
\text { 3. Expectation }\end{array}$ \\
\hline & & PERSONAL ATTRIBUTE \\
\hline \multirow{2}{*}{$\begin{array}{l}\text { REWARD SYSTEM } \\
\text { 1. Customer recognition program } \\
\text { 2. Monetary reward } \\
\text { 3. Reputation mechanism }\end{array}$} & & $\begin{array}{l}\text { 1. Current skill and knowledge } \\
\text { 2. Personal belief } \\
\text { 3. Personal type }\end{array}$ \\
\hline & & PERSONAL EVALUATION \\
\hline \multirow{2}{*}{$\begin{array}{l}\text { TRANSPARENCY } \\
\text { 1. Customer role transparency } \\
\text { 2. Outcome transparency } \\
\text { 3. Process transparency }\end{array}$} & & $\begin{array}{l}\text { 1. Affective evaluation } \\
\text { 2. Previous experience } \\
\text { 3. Value equity }\end{array}$ \\
\hline & & CONSTRAINT \\
\hline \multirow[t]{2}{*}{$\begin{array}{l}\text { CONSTRAINT } \\
\text { Low participatory leadership } \\
\text { Unsuitable reward system }\end{array}$} & \multirow{8}{*}{$\begin{array}{l}\text { Individu al participant } \longrightarrow \text { Individual participant } \\
\text { Firm as Facilitator } \\
\text { Firm allows participant to explore opinions and have } \\
\text { fun with other participants without expecting any } \\
\text { paricular outcomes. } \\
\text { Strong engagement of individuals in the community } \\
\text { may encourage them to seek more control over the } \\
\text { co-creation process. }\end{array}$} & Low personal attribute \\
\hline & & $\begin{array}{l}\text { TECHNOLOGY ENABLER AND } \\
\text { CONSTRAINT }\end{array}$ \\
\hline SOCIAL ENABLER & & ASSOCIATTON \\
\hline \multirow{2}{*}{$\begin{array}{l}\text { CONTENT QUALITY } \\
\text { 1. Balance between personal and fact } \\
\text { 2. Usefulness of information }\end{array}$} & & $\begin{array}{l}\text { 1. Association between individual and content } \\
\text { 2. Interpersonal relationship }\end{array}$ \\
\hline & & INTERACTIVITY \\
\hline $\begin{array}{l}\text { EQUALITY } \\
\text { 1. Norm of reciprocity } \\
\text { 2. Perceived of fairness }\end{array}$ & & $\begin{array}{l}\text { 1. Interactive feature } \\
\text { 2. Social translucence } \\
\text { 3. Virtual reality }\end{array}$ \\
\hline $\begin{array}{l}\text { SENSE OF COMMUNITY } \\
\text { 1. Community identity } \\
\text { 2. Obligation to community } \\
\text { 3. Social bond }\end{array}$ & & $\begin{array}{l}\text { PERSISTENCE } \\
\text { 1. Accessibility } \\
\text { 2. Consistent Presentation }\end{array}$ \\
\hline $\begin{array}{l}\text { SIMILARITY } \\
\text { 1. Members' commonality } \\
\text { 2. Shared interest }\end{array}$ & & $\begin{array}{l}\text { VISIBILITY } \\
\text { 1. Knowledge center } \\
\text { 2. Searching tool }\end{array}$ \\
\hline \multirow{2}{*}{$\begin{array}{l}\text { TRUST } \\
\text { 1. Benevolence trust } \\
\text { 2. Integrity trust }\end{array}$} & & $\begin{array}{l}\text { 3. Rating system } \\
\text { 4. Usability }\end{array}$ \\
\hline & & $\begin{array}{l}\text { CONSTRAINT } \\
\text { Low visibility }\end{array}$ \\
\hline
\end{tabular}

Figure 6. Value Co-Creation Ecosystem in Sponsored Online Communities 
When firms sponsor an online community to co-create value with participants, they should employ appropriate reward systems, a degree of participatory leadership, and a certain level of transparency in tasks, processes, and policy. Our findings show that combining the co-creator and facilitator roles will help strengthen social enablers, which help tackle dissatisfaction during the co-creation process and nurture idea creation, loyalty, and engagement. The importance of social enablers in the online communities for value co-creation is undeniable (e.g. Fisher, 2019; Frasquet-Deltoro et al., 2019). However, along with the increase in social enablers, the sponsoring firm also exposes themselves to the challenge of maintaining control over value co-creation in its online community (Healy and McDonagh, 2013). To manage that challenge, the sponsoring firm should engage in appropriate communication and change the model of communication with individual participants to a model of interactive communication within the community. In relation to innovation, the ability to change the communication between participants into interactive communication between firm and individuals will create a dialogue, which aligns online community resources with the firm's goals. This can improve the learning process of the firm, which can eventually lead to innovation (Nambisan et al., 2017; Winkler and Wulf, 2019). In a different situation, such as the spreading of a negative conversation between participants, the sponsoring firm should take considered action (e.g. Brunner et al., 2019; Hornik et al., 2019; Khobzi et al., 2019; Lin et al., 2018). The conversation techniques used to change negative communication into a constructive environment for value co-creation should be based on the overall social situation in the online community (Hauser et al., 2017). Often when the online community enjoys strong social enablers such as sense of community, other participants will also take action to calm down conflicts in the online community.

\subsection{Directions for Future Research}

The above classification framework along with analysis lays groundwork for future research on enablers and constraints in value co-creation in online communities. More specifically, this study proposes the following potential areas for future investigation:

- Constraints in value co-creation: Our analysis reveals that only four studies (Hall and Graham, 2004; Harrison and Waite, 2015; Ind et al., 2013; Wu and Fang, 2010) examined constraints in value co-creation and thus more studies are needed to explore them further. One of the ways to identify constraints is by identifying the mechanisms of affordances that can act as both enablers and constraints. Affordances help us understand constraints by considering constraints as difficulties that individuals encounter during practice (Anderson and Robey, 2017). Affordances in relation to sociomateriality provide avenues for research in information systems by shifting the focus from technology features to technology capabilities. This can help researchers explain why the same technology may have different results in different contexts. Considering technology as an actor with its own capabilities will also help us expand our understanding of the role of technology in value co-creation.

- Exploring the relation between firm related enablers and firm role navigation: The research into online co-creation communities will grow in the future as more firms engage with their customers to create value collaboratively. Our findings from the extensive review of the literature demonstrate an increasing interest in this domain over the past few years, and have revealed opportunities and challenges that offer directions for future research. In particular, future research focus on firm roles and firm related enablers is encouraged. While the classification framework draws attention to firm roles in managing value co-creation, more studies are needed to discuss the juggling between these two firm roles, as a facilitator and as a co-creator. Only four studies explicitly examine the sponsoring firm role as a facilitator (Healy and McDonagh, 2013; Ind and Coates, 2013; Zhang et al., 2015b; Zhao et al., 2015). The relations between these roles and enablers as well as constraints are also still vague. For example, the firm as a co-creator needs to take charge of and engage in a participatory 
leadership, reward systems, and transparency. Will the efforts of the sponsoring firm in fulfilling participants' needs for socialising develop a sense of community, similarity, information quality, and equality in the online community? How should firms navigate these two roles to maintain value co-creation?

- Examining causal relationships between firm, technological and social related enablers, and how they may relate to, or limit each other: Individual related enablers represent three individual attributes, namely, motivation, personal attributes, and evaluation toward the online community. These attributes may either emerge internally from individual participants or occur as a result of peer interactions in the online community (such as positive and negative feelings generated from their interactions). Technological enablers are also the result of individual participants' interpretations of features available in the platform. Our findings suggest potential causal relationships between these enablers. For example, sense of community relates to interactivity afforded by the technology (Stewart Loane et al., 2015). Seeing value co-creation as ecosystems requires an integrative perspective to understand how these actors influence and limit each other. It will be advantageous to explore further how these enablers relate of limit each other. Future research may advance the framework by exploring the dynamic and longitudinal effect on enablers and constraints. In addition, previous studies in knowledge collaboration propose fluidity as the element of online communities that sustains value creation (Faraj et al., 2011; Ransbotham and Kane, 2011). Fluidity refers to movement of participants coming and going in online communities. Interestingly, we found that none of our selected studies discusses fluidity as an important enabler or constraint in value co-creation. Moreover, considering fluidity as an enabler seems to contradict some already defined enablers such as sense of community, trust, and equality. For example, how sense of community is developed if participation is fluid. Faraj et al. (2016) suggest that the rapid trust that exists in online contexts could be one possible explanation of fluidity as being less harmful or even beneficial to value creation. We suggest that this calls for further explanation and more research in the future.

- Contextual Frameworks: Specific types of online communities sponsored by a firm may call for a different result of firm roles, enablers, and constraints. Examples of specific types of firm sponsored online communities are crowdsourcing (Nakatsu et al., 2014), open source online communities (Stewart Loane et al., 2015; Zwass, 2010), and online co-creation brainstorming (Chen et al., 2012). Investigating how firm roles, enablers, and constraints are different in various settings would improve our understanding of the value co-creation process and may have important implications for managing online communities in different contexts.

- Operationalising the classification framework: The proposed framework in Figure 6 provides a basis for the operationalisation of the classification framework (e.g., creating measures). The definition and list of prior research provided in Table 2 can facilitate further measurement of each enabler and constraint. For example, studies have operationalised individual participants' engagement in value co-creation in a number of ways, including: (i) measuring the duration activities in the online communities (Chen et al., 2012), (ii) emotional bonds (Brodie et al., 2013), and (iii) submit ideas (Füller, 2006).

- Guidelines for managing value co-creation: Enablers and constraints described in this paper can help to manage and even evaluate value co-creation in sponsored online communities. Evaluating the communities based on the direct economic benefits inhibits the sponsoring firm in capturing greater benefits from online communities, and, in turn, the firm misses an opportunity to address business challenges (Cothrel, 2000). In the innovation context, measurement based on output of the online communities is challenging because we cannot measure something when we do not know what we are looking for (Monteiro, 2018). We may not be able to measure things that we do not yet know, but we can identify enablers, constraints, and firm roles in the process of value co-creation. Based on that, a baseline can be set and progress above the established baseline can then be assigned. 


\section{Theoretical Implications}

This study discovered a comprehensive set of enablers and constraints based on the four actors identified in the literature review. Value co-creation is shaped by the firm's generative roles as a facilitator and co-creator and by the fluidity of the online community. Our model demonstrates the shift of control from firms to individual participants in online communities, and conceptualises the inter-relationship between various actors in value co-creation. This reflects a situation where firms may be persuasive, but online communities are not a place of corporate control. The co-creation process also depends on how individual participants understand and make meaning of the firm and the technology. By adopting the two firm roles, the sponsoring firm is better able to manage the tensions between control and 'laissez-faire' in order to maintain and sustain value co-creation.

While Vargo and Lusch (2016) introduced service ecosystems in value co-creation and Storbacka et al. (2016) brought these macro concepts to a more observable level, they did not explicate how this ecosystem operates. They put the focus solely on the engagements as the micro foundation for value co-creation and left the service ecosystems in relation to engagements inadequately justified. Through our model, we have bridged the engagements between actors and the service ecosystem and clarified how the ecosystem works through these engagements. Additionally, previous studies in sociomateriality consider technology users as a single actor and do not differentiate the sponsoring firm and the individual participants as different actors. Yet, to the best of our knowledge, no prior studies have examined how a balanced relationship between consumers and firm can be established.

\section{Practical Implications}

This study offers a number of important practical implications for designing co-creation strategies and improving co-creation practices by delineating the resources that can influence value co-creation in online communities.

The firm as a co-creator can take advantage of our list of enablers and constraints in designing the supports for the online community, such as technology, reward systems, and participatory leadership. For example, the findings in Table 2 can guide practitioners in developing platforms that optimise and foster actors' interactions for productive value co-creation. These findings can also guide the appropriation of technology and the social environment so that they support each other. Our results show that individual factors (motivation, personal attributes, and participants' evaluation of the online community) are critical because they can act as enablers or constraints. In the online world, power shifts from the firm to individuals as information about products and companies become more transparent (Sinclaire and Vogus, 2011). This emphasises the active and equal roles of participants in the context of online co-creation communities (Abedin and Babar, 2018). Therefore, the sponsoring firm as a facilitator should understand their participants' characteristics and take action to maintain enablers based on these characteristics. One tactic for gaining a good understanding of the participants is by allowing participants to interact and co-create value in the online community (Brodie et al., 2013; Gebauer et al., 2013)

Our model also acknowledges and emphasises that sponsored online communities need to benefit participants, which will eventually bring value to the firm (Blasco-Arcas et al., 2014; Bugshan, 2015; Ind et al., 2013; Misra et al., 2008; Nambisan and Baron, 2007; Nambisan and Nambisan, 2008; Wiertz and de Ruyter, 2007; Wu and Fang, 2010; Zhang et al., 2017). Our proposed model highlights the importance of supporting value facilitation between participants. Therefore, the sponsoring firm should be able to navigate its roles as a facilitator and co-creator so that the online community remains attractive for participants while creating value for the sponsoring firm. Our findings guide the 
sponsoring firm in developing strategies for aligning the online community to its business goals by raising the firms' awareness of the enablers that are most closely associated with each role and the trade-off between these two roles. It also informs the sponsoring firm when they should shift their role from co-creator and facilitator. For example, if sponsoring firms do not have a long-term goal for an online community, but rather wish to fulfil a specific task, then they may focus on the co-creator role with limited efforts to facilitate value co-creation between participants on the platform (Hall and Graham, 2004). Examples include GE echo imagination challenge (Majchrzak and Malhotra, 2013), Boeing world design team (Piller et al., 2011), and Swarovski enlightened watch design community (Gebauer et al., 2013). In this context, the sponsoring firm should focus on the transparency of processes, outcomes, and participants' roles. On the other hand, if sponsoring firms initiate online communities for a long-term goal such as to find new opportunities, then they have to pay attention to the value facilitation role and develop strong social enablers (Priharsari et al., 2019). Lastly, the extracted enablers and constraints may also help decision makers to assess and monitor their existing communities' environment and take action accordingly. For example, social enablers are helpful for decision makers to understand the level of sense of community and allow them to develop appropriate actions if the level of sense of community is not as expected.

\section{Conclusions and Limitations}

This paper reviewed and synthesised past research in value creation in firm sponsored online cocreation communities and considered the perspectives of participants and other actors. In this research, we recognise and identify the contextual nature of the reviewed literature, and the shapers, enablers, and constraints from the participants' point of view. Enablers and constraints are identified, distilled, classified, and integrated into a classification framework. Because these findings are based on the literature, the limitations of the reviewed papers also apply to this research. This challenge was managed carefully and explained in the quality assessment section. However, this does not guarantee that this study is immune to the common limitations of literature reviews (Boell and CecezKecmanovic, 2015). For example, the dependency on the selected keywords brings the implication that the characteristics only include affordances that relate to value creation.

Our proposed value co-creation model provides a rich picture of value creation in online co-creation communities and facilitates continued enquiry into online community practices. Our findings have led to: (i) the identification of four actors in sponsored online communities; (ii) the uncovering of enablers and constraints for value co-creation in online communities emerging from these four actors; and (iii) the uncovering of two simultaneous roles (co-creator and facilitator) a sponsoring firm should take in value co-creation journey as well as the interrelationship between them. These findings are significant to the development of our understanding of the management of sponsored online communities. Additionally, we also expand the understanding of the service ecosystem proposed by SDL and contribute to the development of sociomateriality theory.

\section{REFERENCES}

Abedin, B. and Babar, A. 2018, "Institutional vs. Non-institutional use of social media during emergency response: A case of twitter in 2014 australian bush fire", Information Systems Frontiers, Vol. 20, No. 4, pp. 729-740.

Anderson, C. and Robey, D. 2017, "Affordance potency: Explaining the actualization of technology affordances", Information and Organization, Vol. 27, No. 2, pp. 100-115.

Bailey, D., Faraj, S., Hinds, P., von Krogh, G., Leonardi, P. and Hall, P. 2019, "Call for papers special issue of organization science: Emerging technologies and organizing", Organization Science, Vol. 30, No. 3, pp. 642-646. 
Barrett, M., Davidson, E., Prabhu, J. and Vargo, S.L. 2015, "Service innovation in the digital age: Key contributions and future directions", MIS Quarterly, Vol. 39, No. 1, pp. 135-154.

Barrett, M., Oborn, E. and Orlikowski, W. 2016, "Creating value in online communities: The sociomaterial configuring of strategy, platform, and stakeholder engagement", Information Systems Research, Vol. 27, No. 4, pp. 704-723.

Blasco-Arcas, L., Hernandez-Ortega, B. and Jimenez-Martinez, J. 2014, "The online purchase as a context for co-creating experiences. Drivers of and consequences for customer behavior", Internet Research, Vol. 24, No. 3, pp. 393-412.

Boell, S.K. and Cecez-Kecmanovic, D. 2014, "A hermeneutic approach for conducting literature reviews and literature searches", Communications of the Association for Information Systems, Vol. 34, pp. 257-286.

Boell, S.K. and Cecez-Kecmanovic, D. 2015, "On being 'systematic'in literature reviews in is", Journal of Information Technology, Vol. 30, No. 2, pp. 161-173.

Booth, S.E. and Kellogg, S.B. 2015, "Value creation in online communities for educators", British Journal of Educational Technology, Vol. 46, No. 4, pp. 684-698.

Braun, C., Braun, C., Batt, V., Batt, V., Bruhn, M., Bruhn, M., Hadwich, K. and Hadwich, K. 2016, "Differentiating customer engaging behavior by targeted benefits-an empirical study", Journal of Consumer Marketing, Vol. 33, No. 7, pp. 528-538.

Brereton, P., Kitchenham, B.A., Budgen, D., Turner, M. and Khalil, M. 2007, "Lessons from applying the systematic literature review process within the software engineering domain", Journal of Systems and Software, Vol. 80, No. 4, pp. 571-583.

Briel, F.V. and Recker, J. 2017, "Lessons from a failed implementation of an online open innovation community in an innovative organization", MIS Quarterly Executive, Vol. 16, No. 1, pp. 35-46.

Brodie, R.J., Ilic, A., Juric, B. and Hollebeek, L. 2013, "Consumer engagement in a virtual brand community: An exploratory analysis", Journal of Business Research, Vol. 66, No. 1, pp. 105114.

Brunner, C.B., Ullrich, S. and De Oliveira, M.J. 2019, "The most optimal way to deal with negative consumer review: Can positive brand and customer responses rebuild product purchase intentions?", Internet Research, Vol. 29, No. 1, pp. 104-122.

Bugshan, H. 2015, "Co-innovation: The role of online communities", Journal of Strategic Marketing, Vol. 23, No. 2, pp. 175-186.

Chen, L., Marsden, J.R. and Zhang, Z. 2012, "Theory and analysis of company-sponsored value cocreation", Journal of Management Information Systems, Vol. 29, No. 2, pp. 141-172.

Cheung, M.F. and To, W. 2016, "Service co-creation in social media: An extension of the theory of planned behavior", Computers in Human Behavior, Vol. 65, pp. 260-266.

Constantinides, E., Brünink, L.A. and Lorenzo-Romero, C. 2015, "Customer motives and benefits for participating in online co-creation activities", International Journal of Internet Marketing and Advertising, Vol. 9, No. 1, pp. 21-48.

Cothrel, J.P. 2000, "Measuring the success of an online community", Strategy \& Leadership, Vol. 28, No. 2, pp. 17-21.

De Wever, B., Schellens, T., Valcke, M. and Van Keer, H. 2006, "Content analysis schemes to analyze transcripts of online asynchronous discussion groups: A review", Computers \& Education, Vol. 46, No. 1, pp. 6-28.

Dinsmore, B. 2019, "Contested affordances: Teachers and students negotiating the classroom integration of mobile technology", Information, Communication \& Society, Vol. 22, No. 5, pp. 664-677.

Dong, J.Q. and Wu, W. 2015, "Business value of social media technologies: Evidence from online user innovation communities", The Journal of Strategic Information Systems, Vol. 24, No. 2, pp. 113-127.

Durach, C.F., Kembro, J. and Wieland, A. 2017, "A new paradigm for systematic literature reviews in supply chain management", Journal of Supply Chain Management, Vol. 53, No. 4, pp. 67-85. 
Elsharnouby, T.H. and Mahrous, A.A. 2015, "Customer participation in online co-creation experience: The role of e-service quality", Journal of Research in Interactive Marketing, Vol. 9, No. 4, pp. 313-336.

Essamri, A., McKechnie, S. and Winklhofer, H. 2019, "Co-creating corporate brand identity with online brand communities: A managerial perspective", Journal of Business Research, Vol. 96, pp. 366375.

Evans, S.K., Pearce, K.E., Vitak, J. and Treem, J.W. 2017, "Explicating affordances: A conceptual framework for understanding affordances in communication research", Journal of ComputerMediated Communication, Vol. 22, No. 1, pp. 35-52.

Faraj, S., Jarvenpaa, S.L. and Majchrzak, A. 2011, "Knowledge collaboration in online communities", Organization Science, Vol. 22, No. 5, pp. 1224-1239.

Faraj, S., Kudaravalli, S. and Wasko, M. 2015, "Leading collaboration in online communities", MIS Quarterly, Vol. 39, No. 2, pp. 393-412.

Faraj, S., Lakhani, K., Monteiro, E. and von Krogh, G. 2016, "Online community as space for knowledge flows", Information Systems Research, Vol. 27, No. 4, pp. 668-684.

Faulkner, P. and Runde, J. 2013, "Technological objects, social positions, and the thransformational model of social activity", MIS Quarterly, Vol. 37, No. 3, pp. 803-818.

Felin, T., Lakhani, K.R. and Tushman, M.L. 2017, "Firms, crowds, and innovation", Strategic Organization, Vol. 15, No. 2, pp. 119-140.

Fernandes, T. and Remelhe, P. 2016, "How to engage customers in co-creation: Customers' motivations for collaborative innovation", Journal of Strategic Marketing, Vol. 24, No. 3-4, pp. 311-326.

Fisher, G. 2019, "Online communities and firm advantages", Academy of Management Review, Vol. 44, No. 2, pp. 279-298.

Frasquet-Deltoro, M., Alarcón-del-Amo, M.-d.-C. and Lorenzo-Romero, C. 2019, "Antecedents and consequences of virtual customer co-creation behaviours", Internet Research, Vol. 29, No. 1, pp. 218-244.

Füller, J. 2006, "Why consumers engage in virtual new product developments initiated by producers", Advances in Consumer Research, Vol. 33, pp. 639-646.

Füller, J. 2010, "Refining virtual co-creation from a consumer perspective", California Management Review, Vol. 52, No. 2, pp. 98-122.

Füller, J., Mühlbacher, H., Matzler, K. and Jawecki, G. 2009, "Consumer empowerment through internet-based co-creation", Journal of Management Information Systems, Vol. 26, No. 3, pp. 71-102.

Gamble, J.R., Brennan, M. and McAdam, R. 2016, "A contemporary and systematic literature review of user-centric innovation: A consumer perspective", International Journal of Innovation Management, Vol. 20, No. 1, 1650011 (45 pages).

Gebauer, J., Füller, J. and Pezzei, R. 2013, "The dark and the bright side of co-creation: Triggers of member behavior in online innovation communities", Journal of Business Research, Vol. 66, No. 9, pp. 1516-1527.

Grönroos, C. 2008, "Service logic revisited: Who creates value? And who co-creates?", European Business Review, Vol. 20, No. 4, pp. 298-314.

Grönroos, C. 2011a, "A service perspective on business relationships: The value creation, interaction and marketing interface", Industrial Marketing Management, Vol. 40, No. 2, pp. 240-247.

Grönroos, C. 2011b, "Value co-creation in service logic: A critical analysis", Marketing Theory, Vol. 11, No. 3, pp. 279-301.

Grönroos, C. 2019, "Reforming public services: Does service logic have anything to offer?", Public Management Review, Vol. 21, No. 5, pp. 775-788.

Grönroos, C. and Voima, P. 2013, "Critical service logic: Making sense of value creation and cocreation", Journal of the Academy of Marketing Science, Vol. 41, No. 2, pp. 133-150. 
Gummerus, J. 2010, "E-services as resources in customer value creation: A service logic approach", Managing Service Quality: An International Journal, Vol. 20, No. 5, pp. 425-439.

Hall, H. and Graham, D. 2004, "Creation and recreation: Motivating collaboration to generate knowledge capital in online communities", International Journal of Information Management, Vol. 24, No. 3, pp. 235-246.

Harrison, T. and Waite, K. 2015, "Impact of co-production on consumer perception of empowerment", The Service Industries Journal, Vol. 35, No. 10, pp. 502-520.

Hasan, N. and Rahman, A.A. 2017, "Ranking the factors that impact customers online participation in value co-creation in service sector using analytic hierarchy process", International Journal of Information Systems in the Service Sector (IIISSS), Vol. 9, No. 1, pp. 37-53.

Hauser, F., Hautz, J., Hutter, K. and Füller, J. 2017, "Firestorms: Modeling conflict diffusion and management strategies in online communities", The Journal of Strategic Information Systems, Vol. 26, No. 4, pp. 285-321.

Healy, J.C. and McDonagh, P. 2013, "Consumer roles in brand culture and value co-creation in virtual communities", Journal of Business Research, Vol. 66, No. 9, pp. 1528-1540.

Heidenreich, S., Wittkowski, K., Handrich, M. and Falk, T. 2015, "The dark side of customer co-creation: Exploring the consequences of failed co-created services", Journal of the Academy of Marketing Science, Vol. 43, No. 3, pp. 279-296.

Henfridsson, O., Nandhakumar, J., Scarbrough, H. and Panourgias, N. 2018, "Recombination in the open-ended value landscape of digital innovation", Information and Organization, Vol. 28, No. 2, pp. 89-100.

Holmström, J. 2018, "Recombination in digital innovation: Challenges, opportunities, and the importance of a theoretical framework", Information and Organization, Vol. 28, No. 2, pp. 107-110.

Hornik, J., Shaanan Satchi, R. and Rachamim, M. 2019, "The joy of pain: A gloating account of negative electronic word-of-mouth communication following an organizational setback", Internet Research, Vol. 29, No. 1, pp. 82-103.

Ind, N. and Coates, N. 2013, "The meanings of co-creation", European Business Review, Vol. 25, No. 1, pp. 86-95.

Ind, N., Iglesias, O. and Schultz, M. 2013, "Building brands together: Emergence and outcomes of cocreation", California Management Review, Vol. 55, No. 3, pp. 5-26.

Jeppesen, L.B. and Frederiksen, L. 2006, "Why do users contribute to firm-hosted user communities? The case of computer-controlled music instruments", Organization Science, Vol. 17, No. 1, pp. 45-63.

Kang, J.-Y. M. 2014, "Repurchase loyalty for customer social co-creation e-marketplaces", Journal of Fashion Marketing and Management, Vol. 18, No. 4, pp. 452-464.

Kannan, V., Mathew, S.K. and Lehner, F. 2019, "Sociomaterial perspective of digital platforms", paper presented at Twenty-Seventh European Conference on Information Systems, Stockholm \& Uppsala, Sweden, 8-14 June 2019, available at https://aisel.aisnet.org/ecis2019 rip/49/ (accessed 10 August 2019).

Kelleher, C., N. Wilson, H., Macdonald, E.K. and Peppard, J. 2019, "The score is not the music: Integrating experience and practice perspectives on value co-creation in collective consumption contexts", Journal of Service Research, Vol. 22, No. 2, pp. 120-138.

Khobzi, H., Lau, R.Y. and Cheung, T.C. 2019, "The outcome of online social interactions on facebook pages: A study of user engagement behavior", Internet Research, Vol. 29, No. 1, pp. 2-23.

Kitchenham, B. 2007, "Guidelines for performing systematic literature reviews in software engineering", Technical Report, ver. 2.3 Ebse Technical Report. Ebse, Keele University and University of Durham.

Kohler, T., Fueller, J., Matzler, K., Stieger, D. and Füller, J. 2011, "Co-creation in virtual worlds: The design of the user experience", MIS Quarterly, Vol. 35, No. 3, pp. 773-88. 
Krippendorff, K. 1989, "Content analysis. In e. Barnouw, g. Gerbner, w. Schramm, t. L. Worth, \& I. Gross (eds.)", International Encyclopedia of Communication, Vol. 1, pp. 403-407.

Laing, A., Keeling, D. and Newholm, T. 2011, "Virtual communities come of age: Parallel service, value, and propositions offered in communal online space", Journal of Marketing Management, Vol. 27, No. 3-4, pp. 291-315.

Laroche, M., Habibi, M.R., Richard, M.-O. and Sankaranarayanan, R. 2012, "The effects of social media based brand communities on brand community markers, value creation practices, brand trust and brand loyalty", Computers in Human Behavior, Vol. 28, No. 5, pp. 1755-1767.

Leonardi, P.M. 2011, "When flexible routines meet flexible technologies: Affordances, constraint, and the imbrication of human and material agencies", MIS Quarterly, Vol. 35, No. 1, pp. 147-168.

Leonardi, P.M. 2013, "Theoretical foundations for the study of sociomateriality", Information and Organization, Vol. 23, No. 2, pp. 59-76.

Lin, H.-H., Yen, W.-C., Wang, Y.-S. and Yeh, Y.-M. 2018, "Investigating consumer responses to online group buying service failures: The moderating effects of seller offering type", Internet Research, Vol. 28, No. 4, pp. 9659-87.

Lusch, R.F. and Nambisan, S. 2015, "Service innovation: A service-dominant logic perspective", MIS Quarterly, Vol. 39, No. 1, pp. 155-176.

MacDonell, S., Shepperd, M., Kitchenham, B. and Mendes, E. 2010, "How reliable are systematic reviews in empirical software engineering?", IEEE Transactions on Software Engineering, Vol. 36, No. 5, pp. 676-687.

Mai, H.T.X. and Olsen, S.O. 2015, "Consumer participation in virtual communities: The role of personal values and personality", Journal of Marketing Communications, Vol. 21, No. 2, pp. 144-64.

Majchrzak, A. and Malhotra, A. 2013, "Towards an information systems perspective and research agenda on crowdsourcing for innovation", The Journal of Strategic Information Systems, Vol. 22, No. 4, pp. 257-268.

Misra, R., Mukherjee, A. and Peterson, R. 2008, "Value creation in virtual communities: The case of a healthcare web site", International Journal of Pharmaceutical and Healthcare Marketing, Vol. 2, No. 4, pp. 321-337.

Monteiro, E. 2018, "Reflections on digital innovation", Information and Organization, Vol. 28, No. 2, pp. 101-103.

Mueller, B. and Urbach, N. 2017, "Understanding the why, what, and how of theories in is research", Communications of the Association for Information Systems, Vol. 41, No. 17, pp. 349-388.

Mynatt, E.D., O'day, V.L., Adler, A. and Ito, M. 1998, "Network communities: Something old, something new, something borrowed", Computer Supported Cooperative Work, Vol. 7, No. 1, pp. 123156.

Nakatsu, R.T., Grossman, E.B. and lacovou, C.L. 2014, "A taxonomy of crowdsourcing based on task complexity", Journal of Information Science, Vol. 40, No. 6, pp. 823-834.

Nambisan, S. 2009, "Virtual customer environments: It-enabled customer co-innovation and value cocreation", in S. Nambisan (ed.), Information Technology and Product Development, Springer US, Boston, MA, pp. 109-127.

Nambisan, S. and Baron, R.A. 2007, "Interactions in virtual customer environments: Implications for product support and customer relationship management", Journal of Interactive Marketing, Vol. 21, No. 2, pp. 42-62.

Nambisan, S., Lyytinen, K., Majchrzak, A. and Song, M. 2017, "Digital innovation management: Reinventing innovation management research in a digital world", MIS Quarterly, Vol. 41, No. 1, pp. 223-238.

Nambisan, S. and Nambisan, P. 2008, "How to profit from a better 'virtual customer environment'", MIT Sloan Management Review, Vol. 49, No. 3, pp. 53-61.

Osatuyi, B. and Turel, O. 2019, "Social motivation for the use of social technologies: An empirical examination of social commerce site users", Internet Research, Vol. 29, No. 1, pp. 24-45. 
Park, E., Im, G., Storey, V.C. and Baskerville, R.L. 2019, "Never, never together again: How postpurchase affect drives consumer outcomes within the context of online consumer support communities", Journal of the Association for Information Systems, Vol. 20, No. 1, pp. 58-104.

Payne, A.F., Storbacka, K. and Frow, P. 2008, "Managing the co-creation of value", Journal of the Academy of Marketing Science, Vol. 36, No. 1, pp. 83-96.

Pee, L. 2016, "Customer co-creation in b2c e-commerce: Does it lead to better new products?", Electronic Commerce Research, Vol. 16, No. 2, pp. 1-27.

Piller, F.T., Vossen, A. and Ihl, C. 2011, "From social media to social product development: The impact of social media on co-creation of innovation", Die Unternehmung, Vol. 65, No. 1, pp. 7-27.

Pongsakornrungsilp, S. and Schroeder, J.E. 2011, "Understanding value co-creation in a co-consuming brand community", Marketing Theory, Vol. 11, No. 3, pp. 303-324.

Prahalad, C.K. and Ramaswamy, V. 2002, "The co-creation connection", Strategy and Business, Vol. 27, No. 2, pp. 50-61.

Priharsari, D., Abedin, B. and Mastio, E. 2019, "Orchestrating firm sponsored communities of interest: A critical realist case study", paper presented at Pacific Asia Conference on Information Systems, 8-12 July 2019, Xi'an, China, available at: http://www.pacis2019.org/wd/Submissions/PACIS2019 paper 112.pdf (accessed 10 August 2019).

Ransbotham, S. and Kane, G.C. 2011, "Membership turnover and collaboration success in online communities: Explaining rises and falls from grace in wikipedia", MIS Quarterly, Vol. 35, No. 3, pp. 613-627.

Roberts, D., Hughes, M. and Kertbo, K. 2014, "Exploring consumers' motivations to engage in innovation through co-creation activities", European Journal of Marketing, Vol. 48, No. 1/2, pp. 147-169.

Schaedel, U. and Clement, M. 2010, "Managing the online crowd: Motivations for engagement in usergenerated content", Journal of Media Business Studies, Vol. 7, No. 3, pp. 17-36.

Seraj, M. 2012, "We create, we connect, we respect, therefore we are: Intellectual, social, and cultural value in online communities", Journal of Interactive Marketing, Vol. 26, No. 4, pp. 209-222.

Sinclaire, J.K. and Vogus, C.E. 2011, "Adoption of social networking sites: An exploratory adaptive structuration perspective for global organizations", Information Technology and Management, Vol. 12, No. 4, pp. 293-314.

Singaraju, S.P., Nguyen, Q.A., Niininen, O. and Sullivan-Mort, G. 2016, "Social media and value cocreation in multi-stakeholder systems: A resource integration approach", Industrial Marketing Management, Vol. 54, pp. 44-55.

Smaliukiene, R., Chi-Shiun, L. and Sizovaite, I. 2015, "Consumer value co-creation in online business: The case of global travel services", Journal of Business Economics and Management, Vol. 16, No. 2, pp. 325-339.

Ståhlbröst, A. and Bergvall-Kåreborn, B. 2011, "Exploring users motivation in innovation communities", International Journal of Entrepreneurship and Innovation Management, Vol. 14, No. 4, pp. 298-314.

Stewart Loane, S., Webster, C.M. and D'Alessandro, S. 2015, "Identifying consumer value co-created through social support within online health communities", Journal of Macromarketing, Vol. 35, No. 3, pp. 353-367.

Storbacka, K., Brodie, R.J., Böhmann, T., Maglio, P.P. and Nenonen, S. 2016, "Actor engagement as a microfoundation for value co-creation", Journal of Business Research, Vol. 69, No. 8, pp. 30083017.

Suseno, Y., Laurell, C. and Sick, N. 2018, "Assessing value creation in digital innovation ecosystems: A social media analytics approach", The Journal of Strategic Information Systems, Vol. 27, No. 4, pp. 335-349. 
Tavakoli, A., Schlagwein, D. and Schoder, D. 2017, "Open strategy: Literature review, re-analysis of cases and conceptualisation as a practice", The Journal of Strategic Information Systems, Vol. 26, No. 3, pp. 163-184.

Tranfield, D., Denyer, D. and Smart, P. 2003, "Towards a methodology for developing evidence-informed management knowledge by means of systematic review", British Journal of Management, Vol. 14, No. 3, pp. 207-222.

Treem, J.W. and Leonardi, P.M. 2012, "Social media use in organizations: Exploring the affordances of visibility, editability, persistence, and association", Communication Yearbook, Vol. 36, pp. 143189.

Vargo, S. and Lusch, R.F. 2004, "Evolving to a new dominant logic for marketing", Journal of Marketing, Vol. 68, No. 1, pp. 1-17.

Vargo, S. and Lusch, R.F. 2016, "Institutions and axioms: An extension and update of service-dominant logic", Journal of the Academy of Marketing Science, Vol. 44, No. 1, pp. 5-23.

Wiertz, C. and de Ruyter, K. 2007, "Beyond the call of duty: Why customers contribute to firm-hosted commercial online communities", Organization Studies, Vol. 28, No. 3, pp. 347-376.

Winkler, T.J. and Wulf, J. 2019, "Effectiveness of it service management capability: Value co-creation and value facilitation mechanisms", Journal of Management Information Systems, Vol. 36, No. 2, pp. 639-675.

Wolfswinkel, J.F., Furtmueller, E. and Wilderom, C.P. 2013, "Using grounded theory as a method for rigorously reviewing literature", European Journal of Information Systems, Vol. 22, No. 1, pp. 45-55.

Wong, T.Y., Peko, G., Sundaram, D. and Piramuthu, S. 2016, "Mobile environments and innovation cocreation processes \& ecosystems", Information \& Management, Vol. 53, No. 3, pp. 336-344.

Wu, S.-C. and Fang, W. 2010, "The effect of consumer-to-consumer interactions on idea generation in virtual brand community relationships", Technovation, Vol. 30, No. 11, pp. 570-581.

Yan, J., Leidner, D.E. and Benbya, H. 2018, "Differential innovativeness outcomes of user and employee participation in an online user innovation community", Journal of Management Information Systems, Vol. 35, No. 3, pp. 900-933.

Zhang, H., Lu, Y., Wang, B. and Wu, S. 2015a, "The impacts of technological environments and cocreation experiences on customer participation", Information \& Management, Vol. 52, No. 4, pp. 468-482.

Zhang, M., Guo, L., Hu, M. and Liu, W. 2017, "Influence of customer engagement with company social networks on stickiness: Mediating effect of customer value creation", International Journal of Information Management, Vol. 37, No. 3, pp. 229-240.

Zhang, M. and Luo, N. 2016, "Understanding relationship benefits from harmonious brand community on social media", Internet Research, Vol. 26, No. 4, pp. 809-826.

Zhang, T., Kandampully, J. and Bilgihan, A. 2015b, "Motivations for customer engagement in online co-innovation communities (occs) a conceptual framework", Journal of Hospitality and Tourism Technology, Vol. 6, No. 3, pp. 311-328.

Zhao, J., Wang, T. and Fan, X. 2015, "Patient value co-creation in online health communities: Social identity effects on customer knowledge contributions and membership continuance intentions in online health communities", Journal of Service Management, Vol. 26, No. 1, pp. 72-96.

Zhao, Y., Chen, Y., Zhou, R. and Ci, Y. 2019, "Factors influencing customers' willingness to participate in virtual brand community's value co-creation: The moderating effect of customer involvement", Online Information Review, Vol. 43, No. 3, pp. 440-461.

Zhao, Y., Zhao, Y., Zhu, Q. and Zhu, Q. 2016, "Conceptualizing task affordance in online crowdsourcing context", Online Information Review, Vol. 40, No. 7, pp. 938-958.

Zhao, Y. and Zhu, Q. 2014, "Evaluation on crowdsourcing research: Current status and future direction", Information Systems Frontiers, Vol. 16, No. 3, pp. 417-434. 
Zwass, V. 2010, "Co-creation: Toward a taxonomy and an integrated research perspective", International Journal of Electronic Commerce, Vol. 15, No. 1, pp. 11-48. 